\title{
The Students' Perception toward Google Jamboard
}

\author{
Niladatika $^{1 *}$ and Hasanuddin ${ }^{2}$ \\ 1,2 Post Graduate program of English Language Education, Universitas Muhammadiyah Parepare, Indonesia \\ *niladatika@sman11pinrang.sch.id
}

\begin{abstract}
The need for innovative teaching media for educators has increased dramatically amid the COVID-19 pandemic. All schools have implemented online learning, in its implementation there are still many obstacles found, such as the method used is more teacher centered so that it does not involve students in teaching due to the many binding rules in this limited face-to-face learning. Therefore, there are many digital tools that can be used for this limited face to face learning.This study uses a quantitative approach through surveys using questionnaires, and qualitative through semi-structured interviews. A total of 71 respondents were involved in the survey study, while 5 respondents were involved in the interviews. This study focuses on two aspects of the implementation of Google Jamboard as a media namely usefulness and students' attitude, as well as interviews. The findings showed that all the items for the aspect of usefulness and attitude give strong agreement. Meanwhile the finding of the interview is matching and supporting the findings of the quantitative study. Respondents showed positive on the implementation of Google Jamboard. In conclusion, the usage of Google Jamboard in e-learning showed a positive response and acceptance by students. Thus, Google Jamboard is suitable as a digital tool to enrich the methods of teaching and learning.
\end{abstract}

Key words: Covid-19, digital tool, Google Jamboard, online learning.

\section{Introduction}

Education in Indonesia during the COVID-19 pandemic, experienced changes in different learning activities starting in early March 2020. Distance learning was the most effective alternative to be implemented during the Covid-19 outbreak in Indonesia, in order to break the increasingly massive chain of distribution. Covid confirmation cases continue to grow and stop the pace of all sectors, both in terms of the economy, education, tourism, and so on. The surge in COVID-19 positive patients continues to occur and is increasing, so there is a need for roles and tips related to efforts to overcome and break the chain of wider spread. One of them is by implementing distance learning, so that student learning activities are carried out from their respective homes. Distance learning is an alternative for the government, so students are required to study from home with parental guidance under teacher coordination. This of course remains the responsibility of the teacher in monitoring the development of student learning both cognitively, affectively, and psychomotorically. Distance learning (PJJ) during the covid-19 pandemic has caused various responses and changes to the learning system that can affect the learning process and the level of development of students in responding to the material presented [1]. To make the learning process effective, it is possible to utilize learning media technology in the form of platforms such as Google classroom, E-learning, Youtube, WAG, Edmodo, 
Zoom, Googlemeet and other platforms [2][3]. However, this does not mean that the implementation of distance learning has been carried out well, because of the obstacles to facilities and infrastructure that do not support the use of technology in learning. The literature in e-learning indicates that not all students will be successful in online learning [4]. This is due to the factors of the learning environment and the characteristics of students. Especially subjects that require detailed explanations and problem-solving steps, one of which is English subjects where the material on English rules is identical to formulas, this of course requires special learning strategies and learning media that support the delivery of material online.

Moreover, The success of teachers in conducting online learning in the Covid-19 pandemic situation is the teacher's ability to innovate in designing, and concocting materials, learning methods and applications that are in accordance with the materials and methods [5][6]. Creativity is the key to success for a teacher to be able to motivate students to stay enthusiastic in online learning and not be a psychological burden. The selection of appropriate learning strategies and media will greatly determine the interest, participation of students, and will minimize the problems faced by teachers in learning. For that, learning English is very important to involve the media to develop students' understanding, so careful planning is needed. The use of Android-based learning media is one of the applications of 2nd century learning styles [7][8].

In a pandemic area, there has been an increasing amount of research on the use of application-based learning media in PJJ. Junaedi used the Canva application as an online media succeeded in increasing students' creative abilities and also greatly helped students in doing assignments. This can be proven by an increase in the percentage score of learning motivation, learning outcomes and student creativity in each cycle [9].

By using another media, the use of Google Sites in online English learning has many benefits, including making it easier for teachers to send or share material in the form of text, images, audio, or video, giving assignments easily, making the material look more attractive and more interesting than before [10]. Moreover, The android-based e-material learning media met the appropriate criteria, namely valid based on the assessment carried out by the validator, fulfilling practical criteria based on student responses and teacher responses, and meeting effective criteria based on posttest scores for high school student learning outcomes. Android-based e-materials that have been developed can improve high school physics learning outcomes, this is indicated by an increase in N-gain of 0.54 [11].

Based on the results of several studies that have been stated above, the author is interested in researching an android and web-based application that can be used in online learning, namely Google Jamboard. Google jamboard is a digital whiteboard that has been integrated with various cloud services[12]. Jamboard is here to facilitate collaboration in real time between educators and students so that they can make learning more interesting and interactive in virtual face-to-face activities [13][14]. Educators can invite students to sketch ideas, solve problems or draw collaboratively. This Google Jamboard can be used very easily either from a smartphone or laptop by logging in to your respective Google account first. In line with saying that students feel happy using the Google Jamboard media because it is clearer in providing explanations so that the material is easier to understand [15][16]. This Google Jamboard application is expected to be an alternative for English teachers in teaching material that requires detailed explanations that are identical to formulas. Based on the phenomenon stated above, researchers are motivated to see students' perceptions in the application of Google Jamboard in learning.

\section{Methodology}

In this study, researchers used quantitative methods, namely through survey. A " 8 item questionnaire' was administered to obtain quantitative input. The data were collected at the end of the even semester of Academic Year 2020/2021 ( June 2021). The respondents were 71 students randomly selected from the eleventh and tenth grade students of SMAN 11 Pinrang. The reason for limiting the sample only to the eleventh and tenth grade students was tha since they had used this application ( google jamboard) they would find no difficulty to properly respond to the questionnaire.

Therefore, to enrich and support the quantitative findings, a focused semi structured was employed. The themes that emerged during the interview sessions were also coded in accordance to the quantitative dimensions from the questionnaire. $10-5$ minutes interview sessions were conducted with 5 volunteers, who were respondents to the questionnaire administered. The rationale for using focused semi structured open ended interviews was to understand the respondents' point of view rather than make generalizations. As in all such interviews, the researchers set the focus of the interview.The descriptive statistics used in this study are frequency, percentage, and score interpretation. The score interpretation is to summarize the respondents' responses to the statements given by the researcher in the questionnaire. The following are the criteria for interpreting the scores based on the interval

\section{Findings and Discussion}

The eight items included in the questionnaire can be divided into two parts. The first parts concentrates on perceived of usefulness of google jamboard in teaching learning process and the second parts concentrates on students attitude regarding google jamboard. 
Table 1. Normality Test of Motivational Orientations and Self-Control

\begin{tabular}{ll}
\hline Interval & Score interpretation \\
\hline $0 \%-19,99 \%$ & Strongly disagree \\
$20 \%-39,99 \%$ & Disagree \\
$40 \%-59,99 \%$ & Neutral \\
$60 \%-79,99 \%$ & Agree \\
$80 \%-100 \%$ & Strongly agree \\
\hline
\end{tabular}

\section{Perceived Usefulness}

The findings related to the perceived of usefulness which consisted with 4 items (as shown in table 2) revealed that all strongly agree with the items given by the researcher. This finding is a bit surprising because all the items showed strongly agree although there are two respondents who do not agree with the first and the second item, and one respondent in the third item. It showed that the google jamboard is usefulness in teaching learning process

Table 2. Overall Level of EFL Learners' Motivational Orientations and Self-Control

\begin{tabular}{|c|c|c|c|c|c|c|c|}
\hline No & Items & STS & TS & $\mathrm{N}$ & $\mathrm{S}$ & ST & Score \\
\hline 1 & $\begin{array}{l}\text { Jamboard helps teaching and learning ses- } \\
\text { sions take place without being physically } \\
\text { face to face }\end{array}$ & 0 & $2(2.8 \%)$ & 0 & $51(71.4 \%)$ & $18(25.7 \%)$ & $83.9 \%$ (strongly agree) \\
\hline 2 & Learners can share ideas in the jamboard & 0 & $2(2.8 \%)$ & 0 & $49(68.6 \%)$ & $20(28.6 \%)$ & $84.5 \%$ (strongly agree) \\
\hline 3 & $\begin{array}{l}\text { Jamboard provides various features that can } \\
\text { monitor students carrying out learning ac- } \\
\text { tivities }\end{array}$ & 0 & $1(1.4 \%)$ & 0 & $58(81.4 \%)$ & $12(17.1 \%)$ & $82.8 \%$ (strongly agree) \\
\hline 4 & $\begin{array}{l}\text { The use of jamboard is very useful for learn- } \\
\text { ing English }\end{array}$ & 0 & 0 & 0 & $51(71 \%)$ & $13(29 \%)$ & $85.6 \%$ (strongly agree) \\
\hline
\end{tabular}

Based on the table above. the fourth item is " the use of a jamboard is very useful for learning English " and gets the highest index with $85.6 \%$. There are 51 respondents who strongly agree with this item.

Based on interview, Not all digital devices are useful and suitable for use in the teaching and learning process, so it is quite difficult for teacher to choose digital devices that can meet the characteristics of usability with the subjects being taught. This can be seen from the views given by respondents in this study.

\footnotetext{
"Yes, Jamboard is useful as a learning and teaching medium because it can be used when we hold online classes and students like me cannot meet face to face to discuss with friends." (Interviewee A)

"...It is said so because teachers and students can share one Jamboard at the same time. So that teachers and students can carry out learning and teaching without any problems..."

"In my opinion, the use of Jamboard media is very useful for both online and face-to-face learning." (Interviewee B)

"...because Jamboard can make it easier for teachers or lecturers to check the results of assignments submitted by students without having to open every folder to check student answers..." (Interviewee C)

"In my opinion, Jamboard is very useful as a medium for learning and teaching. This is because students can convey their ideas using this application. Next, the teacher will review and respond to students' ideas. (Interviewee D)

"... in my opinion as a student who is less active in expressing opinions face to face, the use of Jamboard is very useful because it can encourage brainstorming in carrying out group activities considering its unique characteristics..." (Interviewee 5)
}

In conclusion, the views of respondents indicate that they think Google Jamboard is useful in learning and teaching, especially classes held virtual or online.

\section{Students Attitude towards Google Jamboard}

The findings related to the students' attitude which consisted of 4 items( as shown in table 3) revealed that all strongly agree with the items given by the researcher. This finding is a bit surprising because all the items showed strongly agree although there are two respondents who do not agree with the second and the fourth item. It showed students' attitude toward the acceptance and use of Google Jamboard in teaching and learning.

Based on the table above, the first item is "I believe that jamboard is one of today's learning media " get the highest index with $88,3 \%$. There are 52 respondents who strongly agree with this item.

Digital devices introduced by teachers when carrying out teaching and learning also need to be reviewed and evaluated for the level of acceptance of the devices by students. If the digital device is less popular or less popular 
Table 3. Students Attitude towards Google Jamboard

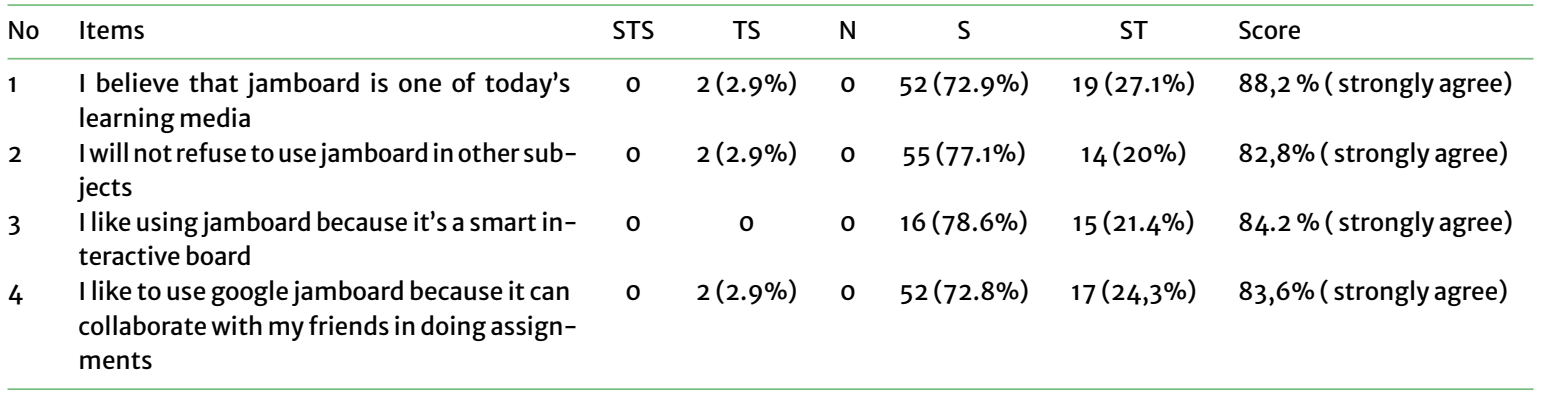

among students, then the teacher should choose another digital device so that the lecture class remains cheerful and active and can attract students' interest in the teaching and learning process. According to the interviewee that have chosen by the researcher.

\footnotetext{
“...I can accept Jamboard as one of today's learning media because Jamboard can simplify the learning process, especially when learning using online methods. It can allow students like me to learn new knowledge as they use new applications to convey thoughts or information." ( Interviewee A)

"Yes, for me Jamboard is a suitable medium to be used in learning today ... Using Jamboard is the use of an application that saves time in the teaching and learning process that faces many obstacles." Interviewee B)

"Yes, I can accept Jamboard as one of today’s learning media." (Interviewee C)

"Yes, I can accept Jamboard as one of today's learning media because it saves a lot of time." (Interviewee D)

"Menurut saya, saya bisa menerima Jamboard sebagai salah satu media pembelajaran saat ini. Hal ini karena pembelajaran virtual sangat penting apalagi di era pandemi saat ini dimana pembelajaran tatap muka tidak diperbolehkan saat ini." (Interviewee E)
}

If students can accept digital tools like Google Jamboard of course they will continue to use these tools in the future. According interviewee A, B,C, and E

\footnotetext{
"I still want to choose Jamboard for future assignments because I find Jamboard very easy to use and allows me or other teammates to be creative in conveying information." (Interviewee A)

"Yes, I still want to choose Jamboard because using this Jamboard really helps me to do my job easily." (Interviewee B)

"Yes, I still want to choose Jamboard because it is very easy to use and has an interesting tool where images can be inserted as wallpaper on every page. In addition, it can also save time answering questions because the tools available on Jamboard are easy to use." (Interviewee C)

"Yes. This is because discussing using Jamboard is very similar to discussing with friends in class." (Interviewee E)
}

One of the advantages of this Google Jamboard is that users do not need long to choose a suitable template to start a task. According Interviewee D

\begin{abstract}
"For me personally, yes because answering questions on Jamboard is easier than using other media. If using 'canva for example', we need to find a beautiful and suitable slide 'template' to make it look beautiful before doing the given task so this can take a lot of time. But this is different if you are given an assignment on the Jamboard because you can continue to answer together and then you can decorate the slides on the Jamboard according to your creativity." (Interviewee D)
\end{abstract}

The level of acceptance in terms of satisfaction with using Google Jamboard is important in the selection of digital tools by lecturers. To maintain an active and student-centered classroom, the selection of digital tools needs to be taken into account. All respondents stated that:they are very satisfied using google jamboard in teaching process

In conclusion, the views of the respondents showed that they expressed satisfaction after using this Google Jamboard. because Google Jamboard can increase user creativity during the learning process

\title{
Conclusion
}

This research shows that the selection and use of learning media, namely Google Jamboard, is appropriate when carrying out online teaching and learning. This can be seen from the survey data and interviews that have been conducted. Survey study data show that respondents strongly agree with the use and acceptance of Google Jamboard, especially when conducting group activities. In fact, the interview data also shows that the level of acceptance of respondents to the use of Google Jamboard is positive. Thus, Google Jamboard is suitable to be used as a digital tool in e-learning and at the same time can meet the demands of 21st century learning that emphasizes creativity, 
communication and technology literacy, information and communication (ICT) students as well as a student-centered teaching and learning process so that the learning process experienced by students is more meaningful.

\section{References}

[1] H. Hikmat,et.al, Efektivitas pembelajaran daring selama masa pandemi Covid-19. LP2M, 2020. Available http: //digilib.uinsgd.ac.id/30625/

[2] R. Habibah, et.al., "Pemanfaatan teknologi media pembelajaran di masa pandemi covid-19". Trapsila: Jurnal Pendidikan Dasar, vol.1, no.2, pp. 1-13, 2020.

[3] L. Mazia, et.al., "Pemanfaatan Google Classroom Sebagai Media Pembelajaran di Tengah Pandemi Covid-19 Pada TPQ Nurul Huda", Jurnal AbdiMas Nusa Mandiri, vol 3, no 1, pp. 9-16, 2021.

[4] D.I. Susanti and J.Y. Prameswari, " Adaptasi Blended Learning di Masa Pandemi COVID-19 untuk Pembelajaran Bahasa Inggris di Sekolah Dasar",Lingua Susastra, vol 1, no 2, pp. 50-61, 2020.

[5] F. Budiyono, "Implementasi Blended Learning di Masa Pandemi Covid 19", In Prosiding Seminar Nasional Pendidikan Biologi, 2007

[6] S. Harnani, Efektivitas Pembelajaran Daring Di Masa Pandemi Covid-19 [online]. Available: https ://bdkjakarta. kemenag.go.id/berita/efektivitas-pembelajaran-daring-di-masa-pandemi-covid-19

[7] R. Yektyastuti and I. Jaslin, "Pengembangan Media Pembelajaran Berbasis Android Pada Materi Kelarutan untuk Meningkatkan Performa Akademik Peserta didik SMA", Jurnal Inovasi Pendidikan IPA UNY., vol 1, no 2, pp. 88-89, 2016

[8] A. D. Astiningsih and C.F. Partana, "Using Android Media for Chemistry Learning Construction of Motivation and Metacognition Ability," International Journal of Instruction, vol 13, no. 1, pp. 279-294, 2020.

[9] S. Junaedy. "Aplikasi Canva Sebagai Media Pembelajaran Daring Untuk Meningkatkan Kemampuan Kreatifitas Mahasiswa Pada Mata Kuliah English For Information Communication And Technology," Bangun Rekaprima: Majalah Ilmiah Pengembangan Rekayasa, Sosial dan Humaniora, pp. 80-89, 2020.

[10] Adzkiya, et.al., "Penggunaan Media Pembelajaran Google Site dalam Pembelajaran Bahasa Inggris Kelas V SD." Educate: Jurnal Teknologi Pendidikan 6, no. 2, pp. 20-31, 2021.

[11] S, Sriwahyuni, "Pengembangan E-Materi Berbasis Android Untuk Meningkatkan Hasil Belajar Fisika Sma" Doctoral Dissertation, Universitas Negeri Makassar, 2020

[12] K.Gourlay and D. Lemmons."Using Google Jamboard to Engage Students Online". In Innovations in Teaching \& Learning Conference Proceedings. Virginia, 2021.

[13] Rosidah and Ati. "Pemanfaatan Google Jamboard Sebagai Media Untuk Pembelajaran Interaktif Selama Pembelajaran Jarak Jauh" (online), available https://lpmpdki.kemdikbud.go.id/ pemanfaatan-google-jamboard-sebagai-media-untuk-pembelajaran-interaktif-selama-pembelajaran-jarak-jauh/

[14] N.R. Virto, N. and M.F.B López, "Google Jam board Interactive Smart Board: Are Innovative Approaches Useful in Personal Branding Assignments". In $2^{\text {nd }}$ Wold Conference on Future of Educacion, Brussels, Belgium, 2020.

[15] L. Christiana. "Pemanfaatan Google Jamboard Dalam Pembelajaran Jarak Jauh Kimia Materi Senyawa Hidrokarbon". SCIENCE: Jurnal Inovasi Pendidikan Matematika dan IPA, vol 1. 1(2), pp. 124-131, August 2021

[16] E. Hasanah, Eva, Pengaruh Media Jamboard Terhadap Motivasi Belajar Dan Hasil Belajar Tajwid, Jakarta: Pascasarjana Institut Ilmu Al-Qur'an (IIQ), 2020. 